ELORE (ISSN 1456-3010), vol. $18-1 / 2011$.

Julkaisija: Suomen Kansantietouden Tutkijain Seura ry.

[http://www.elore.fi/arkisto/1_11/kirjat_hovi2.pdf]

KIRJA-ARVIO

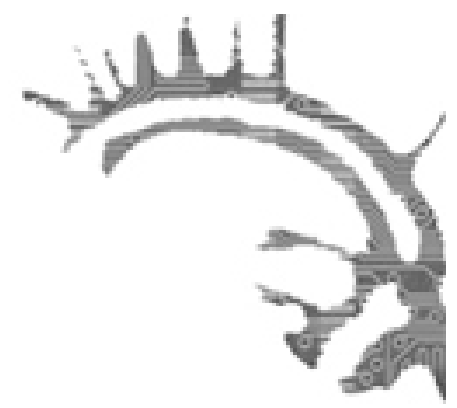

\title{
KUINKA NÄHDÄ METSÄ PUILTA JA LÖYTÄÄ NEULA HEINÄSUOVASTA?
}

RUUSUVUORI, JOHANNA \& NIKANDER, PIRJO \& HYVÄRINEN, MATTI (toim.) 2010: Haastattelun analyysi. Tampere: Vastapaino. 469 sivua.

\section{$\underline{\text { Tuija Hovi }}$}

Haastattelu on nykyisin siinä määrin yleinen tiedonhankinnan muoto, että voidaan puhua jopa "haastatteluyhteiskunnasta", kuten uuden metodioppaan toimittajat Johanna Ruusuvuori, Pirjo Nikander ja Matti Hyvärinen työtään perustelevat. Haastatteluin rakennetut laadulliset aineistot ovat kuuluneet tunnetusti humanististen kulttuuri- ja perinnetieteiden lähestymistapoihin, mutta ovat yhä enemmän vallanneet alaa myös yhteiskuntatieteilijöiden tutkimuksissa. Haastattelun analyysi -artikkelikokoelman kirjoittajat ovat sosiaalitieteilijöitä, jotka haluavat ymmärtää laadullisen tutkimuksen kokonaisvaltaisena ja systemaattisesti rakennettavana tutkimusotteena. Aikaa ei enää tuhlata pohtimalla, missä suhteessa laadullinen ja määrällinen tutkimus ovat toisiaan parempia sosiaalitieteiden kentillä (vrt. esim. Alasuutari 1993; Töttö 2000). Teos on myös onnistuneesti suunnattu eri tieteenaloilla hyödynnettäväksi. Kokoelmassa on peräti 19 artikkelia, jotka johdattavat havainnollisin esimerkein aineiston käsittelyn kysymyksiin ja menetelmiin. En tällä kertaa puuduta lukijaa luettelemalla artikkeleita ja kirjoittajia yksitellen, vaan poimin kokoelmasta itseäni haastattelututkimuksen tekijänä puhuttelevia näkökohtia.

\section{Punainen lanka}

Haastattelun analyysi on tarpeeseen tehty ja luonteva jatko-osa Johanna Ruusuvuoren ja Liisa Tiittulan toimittamalle kirjalle Haastattelu. Tutkimus, tilanteet ja vuorovaikutus (2005), joka nyt käsillä olevaa teosta edeltäen evästää tutkijaa monin tavoin aineiston rakentamisessa ja suhteessa kenttään. Kentältä kotiuduttuaan tutkijan on kuitenkin 
Tuija Hovi: Kuinka nähdä metsä puilta ja löytää neula heinäsuovasta?

luotava kokonaan uusi suhde aineistoonsa, ja se on usein helpommin sanottu kuin tehty. Haastattelun analyysin tarkoitus on opastaa tutkijaa hankitun aineiston uudelleen kohtaamiseen tarjoamalla työkaluja aineiston luokittelun, järjestämisen ja analyysin toteuttamiseen sekä tulkinnan ja keskustelun virittämiseen.

Toimittajat pohjustavat laajaa artikkelikokoelmaa hahmottamalla sille punaista lankaa analyysin vaiheiden kautta. Osatehtävien sykli, joka hermeneuttisena kehänäkin tunnetaan, syntyy aineiston kokoamisen, käsittelyn ja tulkinnan vuorottelusta, joka on tyypillistä laadullisessa tutkimuksessa. Syklin vaiheet eivät valmistu seuraten kronologisesti toisiaan vaan pikemminkin kumuloituvat kierros kierrokselta.

Toimittajat muistuttavat, että tutkimuksen tekemisessä on ennen kaikkea kysymys valinnoista, näkökulmista ja rajaamisesta sekä tehtyjen valintojen perustelemisesta ja liittämisestä teoreettiseen lähtökohtaan tai tieteelliseen keskusteluun. Vastoin monia aiempia laadullisen menetelmän opetuksia he väittävät pontevasti, että "aineisto ei puhu". Sisällönanalyysin tehtävänä on saada aineistosta irti jotain, joka ei ole läsnä suorissa lainauksissa. Tähän tavoitteeseen päästäkseen tutkijan on analyysivaiheessa luovuttava haastattelun teemoista ja kysymyksistä ja tartuttava tutkimuksen teemoihin ja kysymyksiin, siis nostettava abstraktiotasoa. Artikkelit opettavat liikkumista emic- ja etic-käsitteistöjen välillä. Tutkimuskysymys ja tutkijan lukemisentapa ohjaavat aineiston käsittelyä. Tärkeää on analyysin näkyväksi tekeminen.

Laadullisen tutkimuksen yleistettävyyden ja validiteetin kysymykset pohdituttavat itse kutakin usein. Toimittajat muistuttavat, etteivät tutkittavien ja tutkijan intressit ja näkökulma haastattelujen suhteen voi käydä aina yksiin. Oikea tutkimustulos ei siis tarkoita sitä, että se miellyttää tutkittavia tai noudattaa totutun arkiajattelun kaavoja. Ilkka Pietilä (s. 235) kirjoittaa osuvasti siitä, kuinka yleistettävyyden sijaan laadullisessa analyysissa olennaista on suhteuttaminen eli se, miten aineistosta esiin nostetut havainnot liitetään teorioihin ja tieteelliseen keskusteluun.

\section{Antropologiasta sosiologiaAn ja PäINVAStoin}

Pienin yhteinen jaettava - tai ainakin yksi niistä - antropologisten tieteiden ja sosiaalitieteiden piirissä on etnografia, mikä tulee esiin useassa artikkelissa milloin suoraan, milloin rivien välistä. Haastattelujen merkitystä etnografisessa aineistossa suorimmin pohtivat Laura Huttunen ja Anna Rastas omissa artikkeleissaan. Geertziläinen tiheys toteutuu kontekstualisoinnin kautta luettaessa haastatteluaineistoa etnografisesti eli siten, että analyysissä otetaan huomioon kenttä kokonaisuutena erilaisine aineistotyyppeineen - mitä kentällä sitten kulloinkin tarkoitetaan. Myös dialogisen antropologian opetukset näkyvät esimerkiksi Pirkko Nuolijärven ja Liisa Tiittulan vertaillessa mediahaastattelua ja tutkimushaastattelua toisiinsa tiedon tuottamisen muotoina. Monet vuorovaikutusta, tilannekohtaisuutta ja kulttuurisidonnaisuutta tarkastelevat lähestymistavat, kuten vaikkapa Jyrki Pöysän esittelemä asemointinäkökulma palvelevat niin ikään nimenomaan etnografista tiedonintressiä. Siinä mielessä koko teos tarjoaakin kulttuurien tutkijoille paljon tuttua mutta myös uusin tavoin sovelluskelpoista ja oppimisen arvoista luettavaa.

Sisällönanalyysi, jonka nimeen uuden haastattelututkimuksen alkumetreillä on to- 
Tuija Hovi: Kuinka nähdä metsä puilta ja löytää neula heinäsuovasta?

tutusti turvallisinta vannoa, pitää sisällään kuitenkin monia mahdollisuuksia eikä ole yhdentekevää, miten tutkija oman lähestymistapansa määrittelee. Haastattelun analyysi antaa hyvät eväät valintojen tekemiseen ja osoittaa miltei kädestä pitäen, kuinka erityyppiset laadulliset aineistot ja tutkimuskysymykset vaativat seurakseen erityyppiset laadulliset menetelmät. Esimerkiksi Matti Hyvärinen havainnollistaa artikkelissaan kertomuksen analyysin metodeja sen tyypillisen tilanteen suhteen, että haastatteluin tuotettu kerronnallinen aineisto on vaihteleva ja se sisältää erityyppisiä yksiköitä. (Perinnelajianalyysinsä opetelleet folkloristit voivat tässä kohtaa onnitella itseään.) Tästä syystä tutkijan kannattaa hallita useampi kuin yksi analyysimetodi tai malli ja pelkän sisällön rekisteröinnin sijaan pohtia, miksi asioita kerrotaan tietyllä tavalla ja tietyllä hetkellä. Kertomuksen, kerronnan ja kokemuksellisuuden kysymykset ovatkin tyypillisiä haastatteluaineiston teemoja, ja ne laajentavat kuvakulmaa myös vuorovaikutuksen, tilannekohtaisuuden ja identiteetin alueille. Kerronnallisen ympäristön käsite rinnastuu suullisen perinteen näkökulmiin, konventioihin, folkloreen tai vaikkapa uskontoon kontekstina, jossa yksittäiset, henkilökohtaisetkin kertomukset syntyvät.

Identiteetti halutaan kulttuuri- ja yhteiskuntatieteellisessä tutkimuksessa ymmärtää pikemminkin prosessimaisena ja varioivana tilannekuvana kuin kehityksen päätepisteenä. Haastattelupuheessa identiteettejä voi jäljittää monin tavoin, vaikkei niihin kohdentuvia suoria haastattelukysymyksiä olekaan. Vaihtoehtoja näkökulmiksi löytyy tilannekohtaisista rooleista (Pöysä) ja subjektiasemista (Törrönen) jäsenkategorioihin (Nikander). Tällöin tarkastelun kohteena on usein vuorovaikutus keskustelussa. Haastatteluaineisto voi siis olla myös keskusteluaineisto. Haastattelun ja keskustelun erot ja yhtäläisyydet näyttäytyvät tutkittaessa niin kutsuttuja institutionaalisia haastatteluja, esimerkiksi lääkäri-potilas-kohtaamista. Keskustelunanalyysi onkin useassa artikkelissa mukana metodologisena välineenä. Haastattelun ja keskustelun ominaispiirteet erilaisina aineistotyyppeinä pohdituttavat myös silloin, kun tarkasteltavana on sekä ryhmä- että yksilöhaastatteluita. Erilaisina aineistotyyppeinä ne voivat toimia toistensa peilauspintoina. Huomioon otettavana seikkana artikkeleissa keskustellaan myös tutkimushaastattelun kontekstuaalisuudesta ja siitä, kuinka haastattelija itse on osana aineistoaan.

\section{TEKNISET JA EETTISET KOMMERVENKIT}

Jos tutkija ei ole käsityöihmisiä, on laadullisenkin analyysin apuvälineiksi olemassa jo useita koneellisia mahdollisuuksia. Analyysiohjelmat eivät tosin tee koko työtä tutkijan puolesta mutta ne ovat suuria aineistokorpuksia käsiteltäessä hyödyllisiä apuvälineitä aineiston hallintaan ja arkistointiin. Keskeisimmät käyttömahdollisuudet liittyvät aineiston tallennukseen, luokitukseen ja luokkien välisten suhteiden rakentamiseen sekä taustamuuttujien vertailuun. Ennen näiden hyötyjen saamista tutkijan on kuitenkin koodattava aineistonsa niin, että konekin sen ymmärtää. Koodausperiaatteet seuraavat pitkälti grounded theory -analyysimenetelmän kaltaista systematiikkaa.

Aineisto on tietysti saatava ensin koodauskuntoon, toisin sanoen se on muokattava tekstimuotoon. Litterointi tuntuu sitä turhauttavammalta mitä suurempi aineisto on, ja ihailua saa osakseen se, jolla on varaa teettää tylsä työ toisella. Näin ei pitäisi 
Tuija Hovi: Kuinka nähdä metsä puilta ja löytää neula heinäsuovasta?

kuitenkaan olla, sillä jo haastatteluaineiston litterointi on osa sen analysointia, kuten Ruusuvuori ja Nikander muistuttavat. Litterointiakin ohjaavat monet metodologiset valinnat. Ei siis ole yhdentekevää, millä tarkkuudella tallenne tekstualisoidaan, sillä sekin on jo tulkintaa alun perin puhutusta.

Kielen tarkkuus tulee erityisen keskeiseksi kysymykseksi, kun tutkija operoi vieraalla kielellä. Pietilä tuo esiin tärkeän näkökulman tilanteessa, jossa tutkimusprojekteilta vaaditaan kansainvälisyyttä, tutkijoiden liikkuvuus lisääntyy ja maahanmuuttotutkimus tuo omat haasteensa kielikysymyksiin. Pelkkä kielitaito ei riitä, vaan tutkijalta edellytetään myös kulttuurin tuntemusta, kun tulkittavina ovat idiomit, sananlaskut, merkityksenannon tiivistymät ja muut viitteelliset ilmaukset. Myös huumori on kulttuurisidonnaista. Systemaattisinkaan menetelmä ei pelasta yli- tai alitulkinnalta, jos tutkijalta puuttuu riittävä kulttuurinen ymmärrys. Apu löytyy jälleen etnografiasta.

Ajatus mahdollisuudesta aineiston kaikki piirteet tavoittavaan kaikenkattavaan analyysiin on kaunis mutta mahdoton. Laadulliselle haastatteluaineistolle on tyypillistä se, että kun teoreettista taustaa ja kysymyksenasettelua muuttaa, myös analyysin tuloksena syntyy toisenlainen kuva ilmiöstä. Niin tästä syystä kuin tutkimusetiikan näkökulmastakin palaaminen tutkimusaineistoon tulisi taata. Arja Kuula ja Liisa Tiitinen päättävät teoksen artikkelillaan aineiston jatkokäytöstä ja siihen liittyvistä eettisistä kysymyksistä. Jatkokäyttöproblematiikkaan on herätty laajemminkin, sillä esimerkiksi Suomen Akatemian vaatimuksiin on kirjattu tutkimussuunnitelmassa esitettävä selvitys aineistonhallintasuunnitelmasta, siis siitä, miten hankkeen tutkimusaineistot tullaan hankkimaan, miten niitä käytetään, säilytetään ja suojataan, ja miten niiden myöhempi käyttö mahdollistetaan.

Vaikka kirjoittajakunta ja esimerkkiaineistot painottuvatkin vahvasti yhteiskuntatieteelliseen suuntaan, on yhteistä kosketuspintaa kulttuurien tutkimukseen paljon: etnografia, dialoginen antropologia, perinnenäkökulma, kerronnallisuus, kontekstuaalisuus. Niinpä työkalutkin ovat yhteiset. Joka artikkelin lopussa on laatikollinen kyseistä menetelmää koskevaa suositeltavaa kirjallisuutta, mikä palvelee mainiosti kirjan pedagogisia tavoitteita ja sen käyttöä käsikirjana. Haastattelun analyysi ei ole laadullisen tutkimuksen opaskirjana ensimmäinen eikä ainoa mutta poikkeuksellisen kattava, perusteellinen, käytännöllinen ja ajantasainen se on. Jollei tästä paketista löydä yhtään vinkkiä oman haastatteluaineistonsa kanssa työskentelyyn, on syytä keksiä muuta puuhaa.

\section{KiRjallisuUs}

ALASUUTARI, PERTTI 1993: Laadullinen tutkimus. Tampere: Vastąapạino:

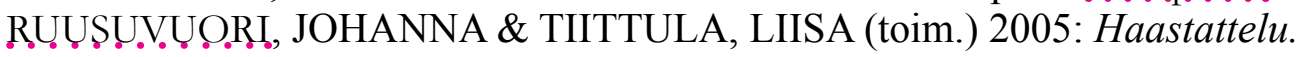
Tutkimus, tilanteet ja vuorovaikutus. Tampere: Vastapaino.

TÖTTÖ, PERTTI 2000: Pirullisen positivismin paluu. Laadullisen ja määrällisen tarkastelua. Tampere: Vastapaino.

Filosofian tohtori Tuija Hovi on Suomen Akatemian tutkijatohtori ja työskentelee Åbo Akademin uskontotieteen oppiaineessa. 